\title{
Generic Structure and Cohesive Devices: A Study on the Final Project Report Presentation of the Accounting Students of Polines Semarang
}

\author{
Suko Raharjo ${ }^{* a}$, Deli Nirmala ${ }^{b}$ \\ ${ }^{a}$ State Polytechnic of Semarang, Jl. Prof. H. Soedarto, S.H., Tembalang, Semarang, Indonesia, 50275 \\ ${ }^{\mathrm{b}}$ Diponegoro University, Jl. Prof. H. Soedarto, S.H., Tembalang, Semarang, Indonesia, 50275
}

\begin{abstract}
A B S T R A C T
This study examines the generic structure and cohesive devices in the Final Project Report (FPR) presentation delivered in English by the Accounting students of Polines. Fourteen randomly selected subjects (10\% of the third graders' population) were involved and audio-recorded during their presentation. The recordings were then transcribed and analyzed using a descriptive-interpretative method. The result shows that the generic structure most presenters used was Greeting and Salutation-Self Introduction-Topic Introduction-Body-Summary-Conclusion, in which the Body mostly consists of Background or Object of the Study, Problem Statement, Aims of the Study, Research Method, and Results and Discussion, and the Summary consists of Conclusion and Suggestion. The major cohesive devices employed were conjunctives of Textual, hypotactic and paratactic types, referents of exophoric and anaphoric types, and repetition as part of lexical cohesion. The transition of stages was marked mostly with referents and specific lexical items. This study may contribute to teaching public speaking of the university students especially in presentation.
\end{abstract}

A R T I C L E I N F O

Paper type:

Research Research

Article history:

Received: 11 December 2017

Revised: 19 February 2018

Accepted: 19 February 2018

Keywords:

- Generic structure

- Cohesive devices

- Final Project Report presentation

\section{Introduction}

On completing their study at the State Polytechnic of Semarang or Polines for short, all students are required to do a final project and to write a report on the project. This report, called a Final Project Report (FPR), must be presented and defended before a team of examiners during an FPR examination. In some departments within the school system, the FPR presentation must be delivered in English although the Question and Answer session after the presentation remains in Indonesian. Based on the observation and experience in teaching them, I may infer that not all students have been sufficiently prepared for presenting a final project report in this examination. It is interesting, therefore, to see how the students present their FPR in English during the FPR examination.This study aims at explaining the generic structure of FPR presentations, the cohesive devices used in the presentations, and the characteristic devices used to signal transitions of stages in the presentations.

Although presenting an FPR in English is compulsory in the Accounting and Business Administration departments and in some study programs in Electro Engineering department, this study is limited to those FPR presentations in the Accounting Study Program of the Accounting Department simplybecause this is where I

\footnotetext{
${ }^{*}$ Corresponding Author:

E-mail Addresses: paksukopolines@gmail.com (S. Raharjo), delinirmala@live.undip.ac.id (D. Nirmala)
}

doi: http://dx.doi.org/10.14710/parole.v6i2.16885 
have been teaching. Other colleagues are encouraged to study similar presentations in their own departments so that a more comprehensive picture of the object under investigation can be obtained. Understanding the students applying and performing their English knowledge and skills for this real-life, short-term demand for English (i.e. making an FPR presentation) is of a great importance in the never ending process of improving our school's English syllabi.

The objectives of this study, therefore, are identifying the generic structure of the Accounting students' FPR presentations and the cohesive devices used in them, and identifying what devices are used to signal transitions of stages in the presentations.

\section{Underlying Theory}

A lot of studies on genres or generic structure as well as on cohesion or cohesive devices have been conducted for investigating different types of discourse or text. This is probably because of the great values of the findings of such studies that may contribute to linguistic developments and, more importantly, for pedagogical purposes. Several genre studies on FPR were conducted at Polines but they were mainly concerned with the moves in the FPR abstracts (Suroso, 2010) or those in FPR introductions (Romangsi, 2010). Using Swales's (1990) genre approach, Suroso (2010) analyzed 40 abstracts from the FPRs made by two groups of students (i.e. Business Administration and Banking-Finance) and discovered that five types of move were involved in the abstracts made by the two groups: Introduction (I), Objective $(O)$, Method $(M)$, Result $(R)$ and Conclusion $(C)$, but the dominant occurrence was only four patterns, giving a common pattern of IOMRC or IOMR. Meanwhile, Romangsi (2010), using the same approach, studied 24 FPR introductions and found that most of them conformed to the model suggested, i.e. Move 1: Establishing a territory, Move 2: Establishing a niche, and Move 3: Occupying the niche. Some variations were found concerning the sequences in Moves 2 and 3.

A more recent study by Tseng (2011) examined 90 research article abstracts in three applied linguistics journals (i.e. TESOL Quarterly, Applied Linguistics, and Language Learning) from two dimensions: the move structure features and the verb tense of each move. The results showed that the abstracts analyzed tended to take a four-move structure instead of a five-move one as proposed in the literature namely: Background, Purpose, Method, Results and Conclusion, with Background being optional (Weissberg \& Buker, 1990). The study also revealed that since some publishers have word limits on abstract length, authors would usually follow the publisher's guideline accordingly, thus there were differences in the move structure features among the abstracts in the three journals. In terms of the verb tense in each move, the preferred pattern was: the present tense usually occurred in the first, second, and fifth move, while the past tense was often used in the third and fourth moves.

To the best of my knowledge, no prior studies have ever been done on the cohesion (or coherence) of FPR presentations at Polines. This motivated me to conduct research on cohesion since it can show the connectivity of the text, which the students seem not good at. A very good study on cohesion was done by Bae (2001) in which two groups of learners (immersion and English-only) were compared in their performance on writing narrative stories in English. The study, involving 192 Korean first and second grader students, concluded, among others, that the most prominent types of cohesion observed in the narratives across the groups were lexical and referential ties (56\% and 32\% respectively) while coordinating conjunction, ellipsis, and substitution occurred less frequently in the written narratives. This suggested, according to Bae (2001), that reference and lexical ties are more crucial and necessary while the other types of cohesive markers can be present or absent depending on writer/speaker's choice. According to Bae (2001), the dominant reference types were pronominal forms (59\% of total occurrences of reference) and proper nouns (23\%) while prominent types of conjunctive relations were temporal (57\% of all occurrences of coordinating conjunctions) and additive (24\%).

To discuss generic structure, I have to explain what I mean by genre. Genre can be defined as "a staged, goal-oriented, purposeful activity in which speakers engage as members of our culture." (Martin, 1984). Genre can also be defined as a particular class of events that are considered by a discourse community to be the same type, e.g. prayers, sermons, conversations, songs, speeches, poems, letters and novels (Richard, Platt, \& Platt, 1992). According to Swales (1990), genre is a class of communicative events (which may vary in prototypicality) with some shared set of communicative purposes (which are recognized by members of the discourse community who establish the constraints on what is generally acceptable in terms of content, positioning, and form for a particular genre). According to Martin (1984), genres are accompanied with "schematic" or "generic" structures, that is, typical organizational structures that might include a typical beginning, middle, and end. Thus, genres are staged, culturally purposeful activities that users of a language draw on to get things done. 
Reference is a (grammatical) cohesive pattern in which the identity of an item in a text can be retrieved from within the text or from outside it. Four types of reference are identified: anaphoric, cataphoric, exophoric and homophoric (Halliday \& Matthiessen, 2004). The term endophoric referent is used to include those referents the identity of which is recoverable from within the text itself. Anaphoric reference signifies a word or phrase referring to another word or phrase used earlier in a text (Platridge, 2000). For example,

(1) (12) Pusat Koperasi Kartika Diponegoro Semarang is the Center of Army Cooperative in Central of Java and Jogjakarta. (13) This cooperative [was] established on the first [of] April 1954 at Kepodang Street Number 5 Semarang.

The phrase This cooperative in Clause (13) in the above example refers backward to the phrase Pusat Koperasi Kartika Diponegoro Semarang in the previous clause.

Cataphoric reference describes the use of a word or phrase referring to another word or phrase used later in the text. For example,

(1) (27) Here are three classification[s] of activities in Cash Flow statement. (28) And the first, operating activities. ... (31) And the second, investing activities.... (33) And the last, financing activities.

The interpretation of the word here in Clause (27) goes forward to the other parts in the text (Clauses (28), (31) and (33)).

Exophoric reference looks outside the text to the context of situation, just as the example below shows,

(1) (10) In this beautiful occasion, I am ... [deliberately omitted], from D3 program, class Accounting $3 \mathrm{~A},(11)$ would like to present my final project under the tittle .... [deliberately omitted].

The interpretation of the demonstrative pronoun this in Clause (10) goes outside the text to the situation available during the presentation.

Homophoric reference refers to items the identity of which can be retrieved by reference to cultural knowledge in general rather than the specific context of the text. An example from Platridge (2000) on this was: "As soon as we arrived, the waiter asked if we wanted a smoking or a non-smoking table." in which the identity of the waiter is retrieved by reference to the shared cultural knowledge we have of restaurants and what we expect to find there.

Substitution is a cohesive pattern in which a substitute form such as 'one/ones', 'do/does' or 'so' is used to substitute for a noun, a verb, or a clause. Here are some examples from Platridge (2000) in which the substitutes one (in 41), done (in 43) and so (in 44) take the place of voice, gone to sleep, and going to rain respectively.

(41) A: I've lost my voice.

B: Get a new one (Halliday, 1994)

(43) A: Have the children gone to sleep?

B: They must have done (Halliday, 1994)

(44) A: Is it going to rain?

B: I don't think so (Nunan, 1993).

Ellipsis is a cohesive pattern in which an element recoverable by referring to a preceding part in the text is omitted. Ellipsis can occur with a noun, a verb or a clause, as the following examples from Platridge (2000) show,

(5) A: Why didn't you lend him some money?

B: I didn't have any (money) (Halliday, 1994)

(6) A: Have you been working?

B: Yes I have (been working) (Nunan, 1993) 
(7) A: Paul's staying for dinner, isn't he?

B: Is he? He didn't tell me (he was staying for dinner) (Nunan, 1993)

Conjunction is a cohesive pattern in which words (here named conjunctives) such as 'and', 'but', or 'then' are used to join phrases, clauses or sections of a text in ways that their express logical-semantic relationship. There are different types of conjunction. Extending Halliday \& Hasan (1976) work on conjunction, Martin (1992) categorizes conjunctions as additive, comparative, temporal and consequential. Additive conjunctives (such as 'and', 'or', 'moreover', 'in addition', and 'alternatively') draw on the notion of addition in both a positive and contrastive sense. Comparative conjunctives (such as 'whereas', 'but', 'on the other hand', 'likewise', and 'equally') draw on the notion of comparison also in both apositive and negative sense. Temporal conjunctives are items such as 'while', 'when', 'after', 'then', and 'finally'. Consequential conjunctives are items such as 'so that', 'because', 'thus', 'therefore' and 'in conclusion'.

In addition to being one of the categories above, a conjunctive may function as external or internal conjunction, that is, connecting clauses externally as Ideational or phenomenological meanings or internally as Textual meanings (i.e. as a means of staging or organizing the text as a text), respectively. Conjunctives are also distinguished in terms of their paratactic or hypotactic relations. Paratactic conjunctives refer to those connecting (or coordinating) clauses of the same level (able-to-stand-alone clauses) while hypotactic conjunctives refer to those connecting subordinate clauses to their main clauses. A very useful summary of conjunctives was presented by Martin (1992) and can be found in Table 4 in the Appendix. This summary does not list every conjunctive in English, but the table is useful for showing the relationship between those conjunctives serving a cohesive function and those serving to link clauses into clause complexes. Distinctive/Internal conjunctives serve a Textual function, while External/Internal cohesive conjunctives serve either an Ideational or Textual function.

In analyzing conjunction as an aspect of cohesion, according to Gerot \& wignell (1994), the convention is to draw up a reticulum, each clause being numbered and these numbers listed down the page. Internal conjunctive relations are noted to the left of these numbers and external ones to the right, except external additive relation (indicated down the center).

Lexical cohesion is a cohesive pattern in which lexical items are related in a text particularly among content words. The main kinds of lexical cohesion are repetition, synonymy, antonymy, hyponymy, meronymy and collocation (Platridge, 2000). Repetition refers to words repeated in the text as well as words changed to reflect tense or number (e.g. 'feel' and 'felt' or 'feeling' and 'feelings'). Synonymy refers to the relationship between words similar in meaning (e.g. 'customers' and 'patrons'). Antonymy refers to opposite or contrastive meanings (e.g. as 'good' and 'bad'). Hyponymy refers to classes of lexical items having a 'general - specific' or 'a type of' relationship (e.g. 'main course' and 'food'). Meronymy refers to lexical items having a 'whole - part' relation (e.g. 'fish' and 'bones' or 'scales'). Collocation describes associations between words tending to co-occur, in the form of (1) combinations of adjectives and nouns such as 'quality control' or 'discerning customers', (2) combinations of verbs and nouns such as 'eat' and 'food' and (3) pairs of nouns such as 'friends' and 'neighbors'.

According to Halliday \& Hasan (1985), the semantic relation that ties two elements together to create cohesion includes co-reference, co-classification and co-extension. Two items of a text are said to be related coreferentially when they refer to the same thing. For example the word 'towel' and 'it' in the following sentence: "Pick up the towel on the floor and hang it outside."

Co-classification is used to describe a semantic relation where the things, processes, or circumstances to which two cohesive elements refer belong to an identical class but each refers to a distinct member of the class. An example of this would be the word 'does' in the sentence: "I play the piano, and my husband does, too."

When the semantic relation is neither of co-reference nor co-classification but, rather, it refers to something within the same general field of meaning, then it is called co-extension. It is this last type of semantic relation that is further elaborated into synonymy (e.g. 'buy' and 'purchase'), antonymy (e.g. 'strong' and 'weak'), hyponymy (e.g. 'animal' and 'cat'), meronymy (e.g. 'tree' and 'root') and repetition of lexical items. They all serve as cohesive devices that create cohesion to a text.An elaborate summary of these cohesive devices can be seen in Table 5 in the Appendix. Cohesive devices, as the table indicates, are of different types, ranging from those functioning as structural to non-structural cohesion, from those showing organic to componential 
relations, and from grammatical to lexical cohesive devices. Due to a number of limitations, however, not all of these devices will be analyzed in this research.

\section{Research Method}

The object of the study, as the title suggests, is the FPR presentation delivered orally by the students of the Accounting Study Program of the Accounting Department of Polines. Since it would be impossible to analyze oral or spoken data, audio-recording was done during the presentations. The recorded presentations were then transcribed and analyzed. So, actually, it is the transcribed presentations that constitute the object of this study.

In one academic year, around 144 students are enrolled at the Accounting Study Program, divided into 6 classes of 24 students each. Not all these third graders' population are involved in this study because this is simply impossible to do. In this analysis, only $10 \%$ of the population (rounded down to 14 students) are randomly selected.

This is how the data for this study were collected: First, on the day the FPR examination was held, an audio recorder (in the form of a [smart] cellphone) was placed on the examinee's desk and set to ON before the student to be recorded entered the examination room. This is in order not to exert unnecessary psychological burden or barrier on the presenter. Later, when the examination was over, the recordings, which are already in the form of MP3 files, were transcribed into written presentation texts for analysis.

Using a Systemic Functional framework the presentation texts were analyzed for the generic structure and cohesive devices employed in them and how the transitions of stages in the presentation are signaled. To make the analysis easy to do, each clause in the 14 presentations is numbered so that accurate reference can be made concerning which part of the data an analysis or discussion refers to. In order to discover the generic structure of the presentations under investigation, each presentation was divided into parts reflecting the stages of the presentation. The cohesive devices used in the texts were also discovered by reading individual clauses in each text and the devices found were categorized. So, this study is, by nature, of descriptive interpretative analysis type. To help presenting the findings, tabulation is used when necessary. It is unfortunate that triangulation of data that would make the analysis of data more accurate could not be done in this study because of the elapsed time between the time of collecting the data and that of analyzing them.

It should be noted that in their presentation, the students use a PowerPoint slide show projected on a wall screen in conjunction to their presentation. This might be considered an inseparable part of the presentation, but, for ease sake, in the present study this is excluded from the analysis and treated as an exophoric referent. (see Halliday \& Hasan, 1976).

\section{Findings and Discussion}

\subsection{The generic structure of the FPR presentation}

From analyzing all the fourteen presentation texts in terms of their generic structure, it was found that most of them follow the stages of Greeting and Salutation (GS), Self Introduction (SI), Topic Introduction (TI), the Body (B), the Summary (S) and the Conclusion (see Table 6 in the Appendix for the details). The Body of the presentation itself may consist some or all of the following sub-stages: Background of Study (Bg), Object of Study (OS), Problem Identification or Problem Statement (PI/PS), Research Objectives or Aims of Study (RO/AS), Method of Investigation or Research Method (MI/RM), Literature Review or Theoretical Framework (LR/TF) and Results and Discussion (R\&D). Meanwhile, the Summary normally consists of Conclusion (Con.) and Suggestion (Sug.)

As Table 1 below indicates, the six stages of development in the presentation (i.e. GS, SI, TI, B, S, and C) can be found in all presentations except in Presentations 11 and 13, in which the presenter did not summarize the presentation, and in Presentation 2, in which the Conclusion was not given. The table also indicates that 2 presenters (no. 2 and 14) switched stages 2 and 3 and introduced their topic first and themselves later instead of introducing themselves and then the topic. 
Table 1. Distribution of the Stages in the Presentations

\begin{tabular}{lllllll}
\hline Data & Stage 1 & Stage 2 & Stage 3 & Stage 4 & Stage 5 & Stage 6 \\
\hline Presentation 1 & GS & SI & TI & B & S & C \\
Presentation 2 & GS & TI $\rightarrow$ SI & B & S & - \\
Presentation 3 & GS & SI & TI & B & S & C \\
Presentation 4 & GS & SI & TI & B & S & C \\
Presentation 5 & GS & SI & TI & B & S & C \\
Presentation 6 & GS & SI & TI & B & S & C \\
Presentation 7 & GS & SI & TI & B & S & C \\
Presentation 8 & GS & SI & TI & B & S & C \\
Presentation 9 & GS & SI & TI & B & S & C \\
Presentation 10 & GS & SI & TI & B & S & C \\
Presentation 11 & GS & SI & TI & B & - & C \\
Presentation 12 & GS & SI & TI & B & S & C \\
Presentation 13 & GS & SI & TI & B & - & C \\
Presentation 14 & GS & TI $\rightarrow$ SI & B & S & C \\
\hline Total & 14 & 14 & 14 & 14 & 12 & 13 \\
\hline$\%$ & $100 \%$ & $100 \%$ & $100 \%$ & $100 \%$ & $86 \%$ & $93 \%$ \\
\hline
\end{tabular}

From the analysis it was also found that the Body of the presentation was variedly developed among presenters, but all of them contained these three sub-stages: Bg/OS (Background or Object of Study), RO/AS (Reseach Objectives or Aims of the Study) and R\&D (Results and Discussion). While most presenters started their Body of the presentation after introducing the topic and their selves, there is one presentation in which the Body was - as it were - split and the first part was "forwarded" to function as an introduction to the Body as a whole. In the same presentation the GS stage was also rather lengthy and not straightforward.

The analysis also revealed that in cases where a summary was given by the presenter, most presentations ( 9 out of 12 texts or $75 \%$ ) divided the summary into conclusion and suggestion and only a few (3 texts or 25\%) did not. Among these few, two presenters gave only the conclusion and no suggestion, which is normal in the school context due to the fact that some FPRs do end up without being able to give any suggestion because of the object of the study or the nature of the findings, and one presenter gave only the suggestion without any conclusion, which is rather unsual.

For the complete distribution of the Body parts and the Summary parts see Table 2 below. As we can see there, the only one presenter with all the stages and sub-stages found in the presenstation was Presenter 10 who switched the sub-stages MI/RM with LR/TF, which is not a problem at all.

Table 2. Distribution of the Body and Summary Parts of the Presentations

\begin{tabular}{|c|c|c|c|c|c|c|c|c|}
\hline \multirow{2}{*}{ Data } & \multicolumn{6}{|l|}{ Body } & \multicolumn{2}{|c|}{ Summary } \\
\hline & $\mathrm{Bg} / \mathrm{OS}$ & PI/PS & $\mathrm{RO} / \mathrm{AS}$ & MI/RM & LR/TF & $\mathrm{R} \& \mathrm{D}$ & Con & Sug \\
\hline Prsntn 1 & $\mathrm{v}$ & $\mathrm{v}$ & $\mathrm{v}$ & - & - & $\mathrm{v}$ & $\mathrm{v}$ & $\mathrm{v}$ \\
\hline Prsntn 2 & $\mathrm{v}$ & $\mathrm{v}$ & $\mathrm{v}$ & - & - & $\mathrm{v}$ & $\mathrm{v}$ & $\mathrm{v}$ \\
\hline Prsntn 3 & $\mathrm{v}$ & $\mathrm{v}$ & $\mathrm{v}$ & - & - & $\mathrm{v}$ & $\mathrm{v}$ & - \\
\hline Prsntn 4 & $\mathrm{v}$ & - & $\mathrm{v}$ & - & - & $\mathrm{v}$ & $\mathrm{v}$ & $\mathrm{v}$ \\
\hline Prsntn 5 & $\mathrm{v}$ & $\mathrm{v}$ & $\mathrm{v}$ & $\mathrm{v}$ & - & $\mathrm{v}$ & $\mathrm{v}$ & $\mathrm{v}$ \\
\hline Prsntn 6 & $\mathrm{v}$ & $\mathrm{v}$ & $\mathrm{v}$ & - & - & $\mathrm{v}$ & $\mathrm{v}$ & - \\
\hline Prsntn 7 & $\mathrm{v}$ & - & $\mathrm{v}$ & $\mathrm{v}$ & - & $\mathrm{v}$ & $\mathrm{v}$ & $\mathrm{v}$ \\
\hline Prsntn 8 & $\mathrm{v}$ & $\mathrm{v}$ & $\mathrm{v}$ & - & - & $\mathrm{v}$ & $\mathrm{v}$ & $\mathrm{v}$ \\
\hline Prsntn 9 & $\mathrm{v}$ & $\mathrm{v}$ & $\mathrm{v}$ & - & $\mathrm{v}$ & $\mathrm{v}$ & - & $\mathrm{v}$ \\
\hline Prsntn 10 & $\mathrm{v}$ & $\mathrm{v}$ & $\mathrm{v}$ & $\mathrm{v} \longleftrightarrow$ & $\mathrm{v}$ & $\mathrm{v}$ & $\mathrm{v}$ & $\mathrm{v}$ \\
\hline Prsntn 11 & $\mathrm{v}$ & - & $\mathrm{v}$ & $\mathrm{v}$ & - & $\mathrm{v}$ & - & - \\
\hline Prsntn 12 & $\mathrm{v}$ & - & $\mathrm{v}$ & $\mathrm{v}$ & - & $\mathrm{v}$ & $\mathrm{v}$ & $\mathrm{v}$ \\
\hline Prsntn 13 & $\mathrm{v}$ & - & $\mathrm{v}$ & $\mathrm{v}$ & - & $\mathrm{v}$ & - & - \\
\hline Prsntn 14 & $\mathrm{v}$ & $\mathrm{v}$ & $\mathrm{v}$ & - & - & $\mathrm{v}$ & $\mathrm{v}$ & $\mathrm{v}$ \\
\hline Total & 14 & 9 & 14 & 6 & 2 & 14 & 11 & 10 \\
\hline$\%$ & $100 \%$ & $64 \%$ & $100 \%$ & $43 \%$ & $14 \%$ & $100 \%$ & $79 \%$ & $71 \%$ \\
\hline
\end{tabular}

The relationship between the generic structure and the cohesive devices used to signal the transitions from one stage or sub-stage to the other will be discussed later in this part. Meanwhile, suffice it to say here that the staging of the students' presentation seemed to be very much influenced by the outline given in the FPR Guideline in which the students are suggested to organize their report using the following stages of development: 
Introduction-Theoretical Framework-Method of Investigation-Result and Discussion-Conclusion and Suggestion. (see Figure 1 in the Appendix for an example of the FPR Outline given in the FPR Guideline).

\subsection{The cohesive devices employed in the presentations}

Conjunction. On analyzing the data it was found that the conjunctions used areof three types: those functioning as Textual conjunction, those connecting independent clauses (i.e. having paratactic relation) and those connecting subordinate clauses to their main clauses (see Table 7, Table 8, Table 9 in the Appendices for the details). Textually, most conjunctions were used as temporal sequence connectors, that is, to signal transition of messages. Syntactically, while $24 \%$ of the conjunctions were of paratactic type, $28 \%$ conjunctives were used hypotactically to relate subordinate clauses to their main clauses. This means that most presenters were able to use complex sentences in their presentation. Some presenters, however, seemed not confident enough to use both hypotactic and paratactic conjunctions as only a few of them appeared in their presentation. Some presenters (e.g. Data 5, 7 and 13) even used no paratactic conjunction in their presentation. This means that most of their ideas were expressed using simple clauses.

Reference. Referents can refer exophorically to context of culture or context of situation or endophorically to the text; it can be verbal or non-verbal. And verbal referent can refer backward (anaphoric) or forward (cataphoric) 0. This analysis, however, is focused on reference types of grammatical cohesive devices, comprising pronominal, demonstrative, definite article and comparative referents. From the analysis we can see that most referents used by the presenters are in the form of definite article 'the' (63\%) referring exophorically and endophorically/anaphorically, and pronominals (24\%) mostly referring exophorically to the presenter (such as $I, m e$ and $m y$ ), to the presenter and the audience (such as we, our and $u s$ ), to the audience alone (e.g. you or your), or to something else, particularly what is shown on the wallscreen (e.g. this). There is one cataphoric case in the data, as can be seen below:

(4) (77) It has been previously stated (78) that net income on an accrual basis does not indicate the company's cash flow.

The referent 'It' in Clause (77) refers forward to the whole Clause (78), a case which is called post-posed subject (Halliday \& Matthiessen, 2004).

Lexical cohesion. Lexical cohesion refers to the relationships between and among words in a text (Gerot \& wignell, 1994). According to Hasan (1984) there are 8 categories of lexical cohesion, namely: repetition (including inflection and derivation), synonymy (similarity of meaning), antonymy (contrastive meaning), hyponymy (class and subclass), meronymy (whole-part relation), equivalence (the same in the context of text), naming (a participant's name mentioned) and semblance (two or more items resembling each other). In this study focus was given to the general type of lexical cohesion. From the analysis we can see that most lexical cohesive devices employed in the text were of repetition type, making 62 chains (71\%) with 392 tokens (87\%). This means that the most frequently used lexical devices are of repetition.

\subsection{Cohesive devices used as stage markers}

Now we come to presenting the result of the analysis of the cohesive devices used in signaling the transition of stages in the presentation.

As Table 10 in the Appendix shows, the total number of devices initiating the move from one stage to another is 121 items (this is excluding the first utterances marking the beginning of the presentation, which merely comes in the form of (Islamic) salaam, salutation or greeting). As Table 10 indicates, most of the transition markers consist of grammatical cohesive devices in the form of referents (26\%) used both exophorically (for example, referring to the speaker) and endophorically/anaphorically (i.e. referring to a part of the text that has previously been mentioned) and Textual conjunctives (25\%).

The lexical cohesive devices, on the other hand, were minimally used (only 1\%) but lexical items are used frequently in this case. Very often the transition of stages is marked with what the next stage is going to be about, e.g. Background of the Study, Problem Statement, or Results and Discussion, which was directly available as the presenter moved his or her screen forward to the next presentation slide. This study actually excludes Thematic analysis of texts from the discussion, but it turned out that some stage transitions could not 
be explained without reference to Thematic structure of texts. As we can see from the table, $15 \%$ of the transition items were in the form of marked Themes, that is, Themes which are not the Subject of the clause. Some examples of these are expressions like 'In this beautiful occasion', 'In this opportunity', and 'From the discussion'.

Table 3. Recapitulation of the Devices Used in Signaling the Transition of Stages in the Presentation

\begin{tabular}{llll}
\hline No. & Type of device & Total Number & $\mathbf{\%}$ \\
\hline 1. & Grammatical cohesion: & $\mathbf{6 4}$ & $\mathbf{5 3 \%}$ \\
& a. Reference & 32 & $26 \%$ \\
& b. Ellipsis & 2 & $2 \%$ \\
& c. Textual conjunction & 30 & $25 \%$ \\
\hline 2. & Lexical cohesion: & $\mathbf{3 4}$ & $\mathbf{2 8 \%}$ \\
& a. Repetition & 1 & $1 \%$ \\
& b. Lexical item & 33 & $27 \%$ \\
\hline 3. & Other: & $\mathbf{2 3}$ & $\mathbf{1 9 \%}$ \\
& a. Marked Theme & 18 & $15 \%$ \\
& b. Vocative Theme & 1 & $1 \%$ \\
& c. Interpersonal Theme & 1 & $1 \%$ \\
& d. Other Theme & 3 & $2 \%$ \\
\hline & Total number of items & $\mathbf{1 2 1}$ & $\mathbf{1 0 0 \%}$ \\
\hline
\end{tabular}

\section{Conclusion}

From the analysis done to the FPR presentations a number of conclusions can be drawn: Firstly, in terms of the generic structure of the presentation, most presenters developed their presentation using the GS (Greeting and Salutation)-SI (Self Introduction)-TI (Topic Introduction)-B (Body of the Presentation)-S (Summary of the Presentation) $-\mathrm{C}$ (Conclusion) stage. The Body itself was variedly developed among presenters, but all of them contained these three sub-stages: Bg/OS (Background or Object of Study), RO/AS (Reseach Objectives or Aims of the Study) and R\&D (Results and Discussion). The other sub-stages found in the Body include PI/PS (Problem Identification or Problem Statement), MI/RM (Method of Investigation or Research Method) and LR/TF (Literature Review or Theoretical Framework). In cases where a Summary was given by the presenter, most presentations ( 9 out of 12 texts or $75 \%$ ) divided the Summary into Conclusion and Suggestion and only a few ( 3 texts or $25 \%$ ) did not.

Secondly, in terms of the cohesive devices employed in the presentations, most presenters used both grammatical as well as lexical cohesive devices. The grammatical cohesive devices used include referents and conjunctives. The referents used were exophoric (referring to external entities), and endophoric (referring to entities in the text). Most of the endophoric referents were anaphoric (referring backward to the part or item already stated or mentioned). Some conjunctives were used Textually to signal transition of ideas, some hypotactically to connect subordinate clauses to their main clauses, and some paratactically to join (main) clauses. The lexical cohesion found in the presentation consisted mostly of repetition type.

Thirdly, in terms of the cohesive devices used to signal the transition of stages in the presentation, the analysis shows that most of the transition markers consist of grammatical cohesive devices in the form of referents $(26 \%)$, which are used both as exophoric (e.g. referring to the speaker) and endophoric/anaphoric referents (i.e. referring to a part of the text that has previously been mentioned), and Textual conjunctives (25\%) to signal transitions. The lexical cohesive devices were minimally used (only 1\%) but lexical items were frequently used (27\%), especially in the form of noun phrases telling the audience what the next stage is going to be about, e.g. Background of the Study, Problem Statement, or Results and Discussion. These noun phrases seemed to be the headings of the slides the presenters showed in conjunction with their presentations. These lexical items are not referents but they "exophorically refer" to the presentation slide headings.

Based on the study, I may recommend that further investigation into such presentations be done particularly to uncover the cohesive properties of the texts that have not been uncovered in this study, for example using a Thematic analysis. The more is revealed about the coherence of the presentation, the more information can be shared to the students preparing to give a similar presentation in the future through the teaching-learning process in the classroom. Besides, the suggestions might go to the teacher to highlight the generic structure of the text before presentation is done. 


\section{References}

Bae, J., (2001). Cohesion and Coherence in Children's Written English: Immersion and English-only Classes. In Issues in Applied Linguistics ISSN 1050-4273 Regents of the University of California Vol. 12 No. 1, 51-88. Retrieved on March 10, 2015 from http://languagetesting.info/articles/store/ialreprintbae.pdf

Gerot, L. \& P. Wignell, (1994). Making sense of functional grammar, an Intro-ductory Workbook. Cammeray, NSW: Antipodean Educational Enterprises (AEE).

Halliday, M. A. K., \& C. M. I. M. Matthiessen, (2004). An introduction to functional grammar. Third Ed. NY: Oxford University Press.

Halliday, M. A. K., \& R. Hasan, (1976). Cohesion in English. Essex, England: Longman.

Halliday, M. A. K., \& R. Hasan, (1985). Language, context, and text: Aspects of language in a social-semiotic perspective. Victoria: Deakin University.

Halliday, M. A. K., (1994). An introduction to functional grammar (2nd Ed.). London: Edward Arnold.

Hasan, R., 1984. Coherence and Cohesive Harmony. In J. Flood, (ed). Understanding Reading Comprehension. Newark, Delaware: International Reading Association.

Martin, J. R. (1984). Language, register, and genre. In F. Christie (Ed.). Language Studies: Children's Writing, Reader. Geelong, Australia: Deakin University Press.

Martin, J. R. (1992). English text: System and structure. Philadelphia: John Benjamins Publishing Company.

Nunan, D., (1993). Introducing discourse analysis. London: Penguin.

Paltridge, B., (2000). Making sense of discourse analysis. Queensland: AEE.

Richards, J. C., J. Platt, \& H. Platt, (1992). The Longman dictionary of language teaching and applied linguistics. New Ed. Essex: Longman.

Romangsi, I. N., (2010). Moves in introductions of final project reports of Accounting study program of Semarang State Polytechnic. Unpublished thesis. Semarang: Post Graduate Program of Semarang State University.

Suroso, I., (2010). Moves in abstracts of final project reports in Semarang State Polytechnic. Unpublished thesis. Semarang: Post Graduate Program of Semarang State University.

Swales, J. M., (1990). Genre Analysis: English in academic and research settings. Cambridge: Cambridge University Press.

Tseng, F. P., (2011). Analyses of move structure and verb tense of research article abstracts in Applied Linguistics Journals. In International Journal of English Linguistics. Vol. 1, No. 2, $\begin{array}{lllll}\text { September.Retrievedon } & \text { July } & 10, & 2015 & \text { from }\end{array}$ http://www.ccsenet.org/journal/index.php/ijel/article/view/10189/8499

Weissberg, R., \& S. Buker, (1990). Writing up research: Experimental research report writing for students of English. New Jersey: Prentice Hall. 


\section{Appendices}

Table 4. Summary of Conjunctions

\begin{tabular}{|c|c|c|c|c|}
\hline & Distinctive Internal & External/ Internal Cohesive & Paratactic & Hypotactic \\
\hline \multirow[t]{2}{*}{ Additive } & $\begin{array}{l}\text { moreover } \\
\text { in addition to }\end{array}$ & and & and & besides \\
\hline & alternatively & or & or & if not $\ldots$ then \\
\hline \multirow[t]{2}{*}{ Comparative } & $\begin{array}{l}\text { equally } \\
\text { that is }\end{array}$ & likewise & $\mathrm{so}^{\wedge}$ Finite & like, as, as if, like when \\
\hline & oh the other hand & $\begin{array}{l}\text { in contrast } \\
\text { instead }\end{array}$ & but & $\begin{array}{l}\text { whereas } \\
\text { except that }\end{array}$ \\
\hline Temporal & $\begin{array}{l}\text { at the same time } \\
\text { finally } \\
\text { at first }\end{array}$ & $\begin{array}{l}\text { meanwhile } \\
\text { throughout } \\
\text { previously } \\
\text { thereupon }\end{array}$ & $\begin{array}{l}\text { and } \\
\text { meanwhile } \\
\text { then }\end{array}$ & $\begin{array}{l}\text { while, when, } \\
\text { as long as, } \\
\text { after, since, } \\
\text { now that }\end{array}$ \\
\hline \multirow[t]{4}{*}{ Consequential } & $\begin{array}{l}\text { to this end } \\
\text { then }\end{array}$ & $\begin{array}{l}\text { to this end } \\
\text { then } \\
\text { otherwise }\end{array}$ & $\begin{array}{l}\text { so } \\
\text { so }\end{array}$ & $\begin{array}{l}\text { so that, lest, so as, in case, if, } \\
\text { even if, unless }\end{array}$ \\
\hline & $\begin{array}{l}\text { in conclusion } \\
\text { after all }\end{array}$ & $\begin{array}{l}\text { therefore } \\
\text { for }\end{array}$ & so & because, as, since \\
\hline & $\begin{array}{l}\text { nevertheless } \\
\text { admittedly }\end{array}$ & $\begin{array}{l}\text { however } \\
\text { yet }\end{array}$ & but & although, in spite of \\
\hline & in this way & thus & and thus & by, thereby \\
\hline
\end{tabular}

CHAPTER I. INTRODUCTION

1.1 Background of the Study

1.2 Problem Statement

1.3 Aims of the Study

CHAPTER II. THEORETICAL FRAMEWORK

2.1 The Theories Underlying the Study

2.2 Previous Studies

CHAPTER III. METHOD OF INVESTIGATION
3.1 Objects of the Study
3.2 Population and Sample
3.3 Method of Collecting Data

CHAPTER IV. RESULT AND DISCUSSION

4.1 General View of the Object/Respondent

4.2 Results of the Analysis

4.3 The Discussion of the Results

CHAPTER V. CONCLUSION AND SUGGESTION
5.1 Conclusion
5.2 Suggestion

Figure 1. Outline of the FPR Content in the FPR Guideline (an example) 
Table 5. Summary of Cohesive Devices

NON-STRUCTURAL COHESION

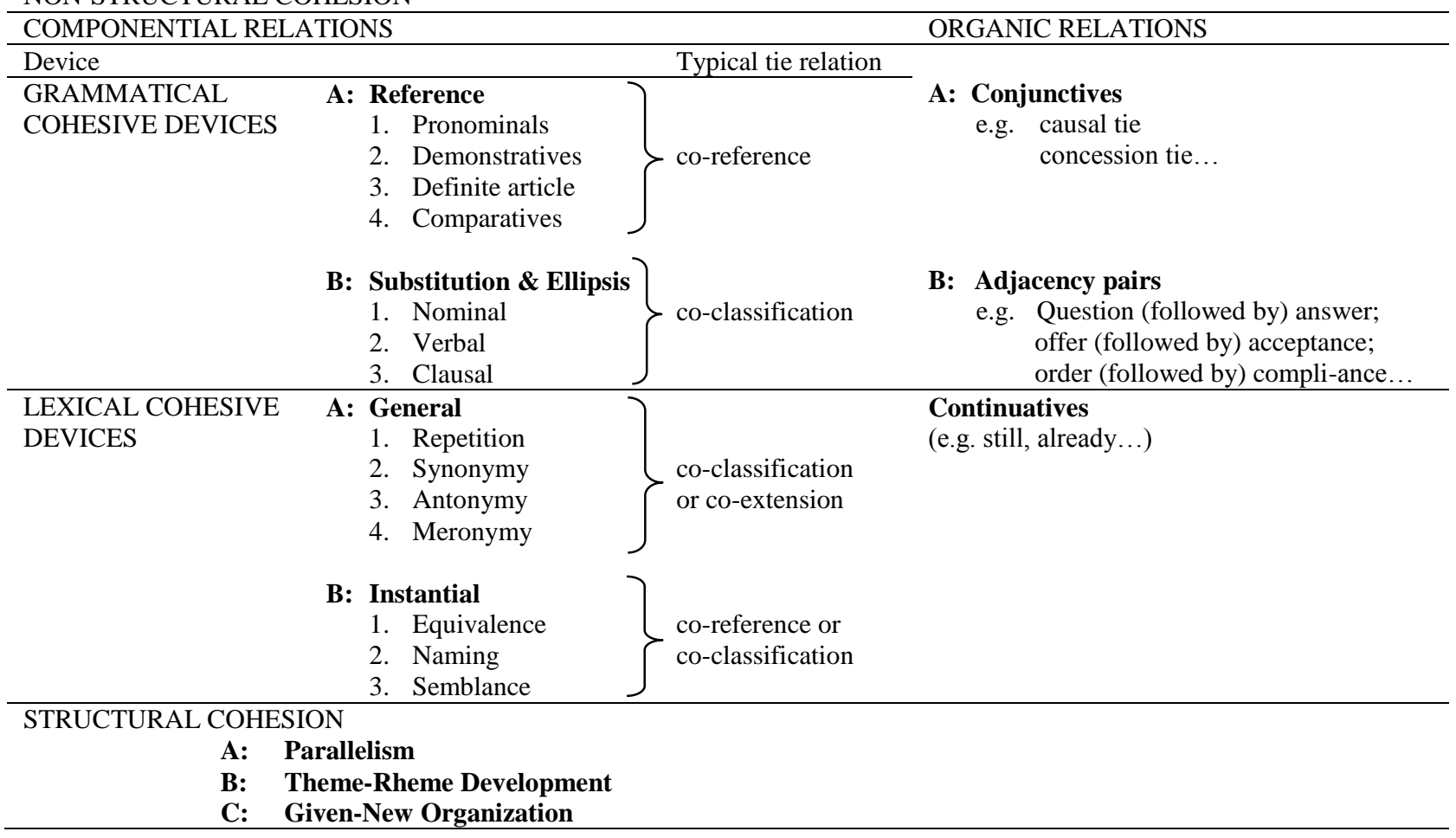


Table 6. Stages in Each Presentation and the Clauses Representing Each Stage

\begin{tabular}{|c|c|c|c|c|c|c|c|c|c|c|c|}
\hline \multirow[t]{2}{*}{1} & \multirow{2}{*}{$\begin{array}{l}\text { GS }(\& \operatorname{Pr}) \\
\text { c. } 1-9\end{array}$} & \multirow[t]{2}{*}{ SI c. 10} & \multirow{2}{*}{$\begin{array}{l}\text { TI } \\
\text { c. } 11\end{array}$} & \multicolumn{4}{|l|}{ B c. $12-80$} & \multicolumn{2}{|l|}{ S c. $81-90$} & \multirow{2}{*}{$\begin{array}{l}\text { C c.91- } \\
93\end{array}$} & \\
\hline & & & & $\begin{array}{l}\mathrm{Bg} / \mathrm{OS} \\
\text { c. } 12-20\end{array}$ & $\begin{array}{l}\mathrm{PI} / \mathrm{PS} \\
\text { c. } 21-23\end{array}$ & $\begin{array}{l}\text { RO/AS } \\
\text { c. } 24-26\end{array}$ & $\begin{array}{l}\text { R\&D } \\
\text { c. } 27-80\end{array}$ & $\begin{array}{l}\text { Con } \\
\text { c. } 81-86\end{array}$ & $\begin{array}{l}\text { Sug } \\
\text { c. } 87-90\end{array}$ & & \\
\hline 2 & \multirow[t]{2}{*}{ GS c. 1} & \multirow[t]{2}{*}{ TI c. $2-3$} & \multirow{2}{*}{$\begin{array}{l}\text { SI c.4- } \\
5\end{array}$} & \multicolumn{4}{|l|}{ B c.6-78 } & \multicolumn{2}{|l|}{ S c.79-86 } & \multirow{2}{*}{ X } & \\
\hline & & & & $\begin{array}{l}\mathrm{Bg} / \mathrm{OS} \\
\text { c. } 6-21\end{array}$ & $\begin{array}{l}\mathrm{PI} / \mathrm{PS} \\
\text { c.22-27 }\end{array}$ & $\begin{array}{l}\mathrm{RO} / \mathrm{AS} \\
\text { c. } 28-31\end{array}$ & $\begin{array}{l}\text { R\&D } \\
\text { c.32-78 }\end{array}$ & $\begin{array}{l}\text { Con } \\
\text { c. } 79-81\end{array}$ & $\begin{array}{l}\text { Sug } \\
\text { c. } 82-86\end{array}$ & & \\
\hline \multirow[t]{2}{*}{3} & \multirow{2}{*}{$\begin{array}{l}\text { GS (\&Pr) } \\
\text { c. } 1-15\end{array}$} & B & \multirow{2}{*}{$\begin{array}{l}\text { SI } \\
\text { c. } 42- \\
43\end{array}$} & \multirow{2}{*}{$\begin{array}{l}\text { TI } \\
\text { c. } 44-46\end{array}$} & \multicolumn{3}{|c|}{ B c. $47-87$} & \multirow{2}{*}{$\begin{array}{l}\text { S c.88- } \\
96\end{array}$} & \multirow{2}{*}{$\begin{array}{l}\text { C c. } 97- \\
100\end{array}$} & & \\
\hline & & $\begin{array}{l}\text { BG/OS } \\
\text { c. } 16-41\end{array}$ & & & $\begin{array}{l}\mathrm{PI} / \mathrm{PS} \\
\mathrm{c} .47-50\end{array}$ & $\begin{array}{l}\mathrm{RO} / \mathrm{AS} \\
\mathrm{c} .51-52\end{array}$ & $\begin{array}{l}\text { R\&D } \\
\text { c.53-87 }\end{array}$ & & & & \\
\hline \multirow[t]{2}{*}{4} & \multirow[t]{2}{*}{ GS c. $1-2$} & \multirow[t]{2}{*}{ SI c.3-4 } & \multirow[t]{2}{*}{ TI c. 5} & \multicolumn{3}{|l|}{ B c.6-108 } & \multicolumn{2}{|c|}{ S c.109-129 } & \multirow{2}{*}{$\begin{array}{l}\text { C } \\
\text { c. } 130- \\
132\end{array}$} & & \\
\hline & & & & $\begin{array}{l}\mathrm{Bg} / \mathrm{OS} \\
\text { c.6-34 }\end{array}$ & $\begin{array}{l}\text { RO/AS } \\
\text { c.35-37 }\end{array}$ & $\begin{array}{l}\text { R\&D } \\
\text { c.38- } \\
108\end{array}$ & $\begin{array}{l}\text { Con } \\
\text { c.109- } \\
123\end{array}$ & $\begin{array}{l}\text { Sug } \\
\text { c.124- } \\
129\end{array}$ & & & \\
\hline \multirow[t]{2}{*}{5} & GS c. $1-6$ & SI c. $7-8$ & TI & B c. $11-53$ & & & & & S c.54-67 & & $\mathrm{C}$ \\
\hline & & & c. $9-10$ & $\begin{array}{l}\mathrm{Bg} / \mathrm{OS} \\
\text { c. } 11-17\end{array}$ & $\begin{array}{l}\mathrm{PI} / \mathrm{PS} \\
\text { c. } 18-20\end{array}$ & $\begin{array}{l}\mathrm{RO} / \mathrm{AS} \\
\mathrm{c.} 21-23\end{array}$ & $\begin{array}{l}\text { MI/RM } \\
\text { c. } 24-29\end{array}$ & $\begin{array}{l}\text { R\&D } \\
\text { c.30-53 }\end{array}$ & $\begin{array}{l}\text { Con } \\
\text { c.54-64 }\end{array}$ & $\begin{array}{l}\text { Sug } \\
\text { c. } 65-67\end{array}$ & $\begin{array}{l}\text { c. } 68- \\
69\end{array}$ \\
\hline 6 & GS c. 1 & SI c. $2-4$ & TI c.5 & B c.6-33 & & & & S c.34- & C c.38- & & \\
\hline & & & & $\begin{array}{l}\text { Bg/OS } \\
\text { c. } 6-12\end{array}$ & $\begin{array}{l}\mathrm{PI} / \mathrm{PS} \\
\mathrm{c} .13-16 \\
\end{array}$ & $\begin{array}{l}\mathrm{RO} / \mathrm{AS} \\
\mathrm{c} .17-18 \\
\end{array}$ & $\begin{array}{l}\mathrm{R} \& \mathrm{D} \\
\mathrm{c} .19-33 \\
\end{array}$ & 37 & 39 & & \\
\hline 7 & GS c.1-4 & SI c.5-6 & TI & B c. $9-34$ & & & & S c. $35-42$ & & $\bar{C}$ c.43- & \\
\hline & & & c. $7-8$ & $\begin{array}{l}\mathrm{Bg} / \mathrm{OS} \\
\text { c. } 9-15\end{array}$ & $\begin{array}{l}\mathrm{RO} / \mathrm{AS} \\
\mathrm{c} .16-20\end{array}$ & $\begin{array}{l}\text { MI/RM } \\
\text { c. } 21-31\end{array}$ & $\begin{array}{l}\mathrm{R} \& \mathrm{D} \\
\text { c.32-34 }\end{array}$ & $\begin{array}{l}\text { Con } \\
\text { c. } 35-38\end{array}$ & $\begin{array}{l}\text { Sug } \\
\text { c. } 39-42\end{array}$ & 46 & \\
\hline 8 & GS c.1-2 & SI c.3-4 & TI c. 5 & B c. $6-40$ & & & & S c. $41-50$ & & C c.51 & \\
\hline & & & & $\begin{array}{l}\mathrm{Bg} / \mathrm{OS} \\
\text { c.6-12 }\end{array}$ & $\begin{array}{l}\mathrm{PI} / \mathrm{PS} \\
\mathrm{c} .13-15 \\
\end{array}$ & $\begin{array}{l}\text { RO/AS } \\
\text { c. } 16-20 \\
\end{array}$ & $\begin{array}{l}\text { R\&D } \\
\text { c. } 21-40\end{array}$ & $\begin{array}{l}\text { Con } \\
\text { c. } 41-48 \\
\end{array}$ & $\begin{array}{l}\text { Sug } \\
\text { c. } 49-50\end{array}$ & & \\
\hline 9 & GS c. $1-3$ & SI c.4-5 & TI c.6 & B c. $7-37$ & & & & & $\begin{array}{l}\text { S c.56- } \\
57\end{array}$ & $\begin{array}{l}\text { C c.58- } \\
59\end{array}$ & \\
\hline & & & & $\begin{array}{l}\mathrm{Bg} / \mathrm{OS} \\
\text { c. } 7-20\end{array}$ & $\begin{array}{l}\mathrm{PI} / \mathrm{PS} \\
\text { c. } 21-23 \\
\end{array}$ & $\begin{array}{l}\mathrm{RO} / \mathrm{AS} \\
\mathrm{c} .24-26 \\
\end{array}$ & $\begin{array}{l}\text { LR/TF } \\
\text { c. } 27-32\end{array}$ & $\begin{array}{l}\text { R\&D } \\
\text { c.33-55 }\end{array}$ & $\begin{array}{l}\text { Sug } \\
\text { c.56-57 }\end{array}$ & & \\
\hline 10 & $\mathrm{G}(-\mathrm{S}) \mathrm{c} .1$ & SI c. 2 & $\mathrm{TI}$ & B c.5-69 & & & & & & S c. $70-76$ & $\mathrm{C}$ \\
\hline & & & c. $3-4$ & $\begin{array}{l}\mathrm{Bg} / \mathrm{OS} \\
\text { c. } 5-17\end{array}$ & $\begin{array}{l}\mathrm{PI} / \mathrm{PS} \\
\text { c.18-22 }\end{array}$ & $\begin{array}{l}\mathrm{RO} / \mathrm{AS} \\
\mathrm{c} .23-28\end{array}$ & $\begin{array}{l}\mathrm{LR} / \mathrm{TF} \\
\text { c. } 29-45\end{array}$ & $\begin{array}{l}\mathrm{MI} / \mathrm{RM} \\
\text { c. } 46-50\end{array}$ & $\begin{array}{l}\text { R\&D } \\
\text { c.51-69 }\end{array}$ & $\begin{array}{l}\text { Con } \\
\text { c. } 70-75\end{array}$ & $\begin{array}{l}\text { c. } 77- \\
78\end{array}$ \\
\hline 11 & GS c.1-2 & SI c.3-4 & TI c. 5 & B c. $6-58$ & & & & $X$ & C c.59- & & \\
\hline & & & & $\begin{array}{l}\mathrm{Bg} / \mathrm{OS} \\
\text { c.6-15 }\end{array}$ & $\begin{array}{l}\mathrm{RO} / \mathrm{AS} \\
\mathrm{c} .16-19\end{array}$ & $\begin{array}{l}\text { MI/RM } \\
\text { c. } 20-43\end{array}$ & $\begin{array}{l}\text { R\&D } \\
\text { c. } 44-58\end{array}$ & & 60 & & \\
\hline 12 & GS c. $1-4$ & SI c.5-6 & TI c.7 & B c.8-66 & & & & S c. $67-74$ & & C c.75- & \\
\hline & & & & $\begin{array}{l}\mathrm{Bg} / \mathrm{OS} \\
\text { c. } 8-13\end{array}$ & $\begin{array}{l}\mathrm{RO} / \mathrm{AS} \\
\mathrm{c} .14-15 \\
\end{array}$ & $\begin{array}{l}\mathrm{MI} / \mathrm{RM} \\
\mathrm{c} .16-20 \\
\end{array}$ & $\begin{array}{l}\text { R\&D } \\
\text { c. } 21-66\end{array}$ & $\begin{array}{l}\text { Con } \\
\text { c.67-69 } \\
\end{array}$ & $\begin{array}{l}\text { Sug } \\
\text { c. } 70-74\end{array}$ & 77 & \\
\hline 13 & GS c. $1-2$ & SI c. 3 & TI & B c.6-31 & & & & $\mathrm{X}$ & C c.32- & & \\
\hline & & & c. $4-5$ & $\begin{array}{l}\text { Bg/OS } \\
\text { c. } 6\end{array}$ & $\begin{array}{l}\text { RO/AS } \\
\text { c.7-9 }\end{array}$ & $\begin{array}{l}\text { MI/RM } \\
\text { c. } 10-23\end{array}$ & $\begin{array}{l}\text { R\&D } \\
\text { c. } 24-31\end{array}$ & $\Lambda$ & 34 & & \\
\hline 14 & GS c. $1-4$ & TI c.5 & SI c.6- & B c. $10-34$ & & & & S c. $35-43$ & & C c.44 & \\
\hline & & & & $\begin{array}{l}\mathrm{Bg} / \mathrm{OS} \\
\text { c. } 10-20\end{array}$ & $\begin{array}{l}\mathrm{PI} / \mathrm{PS} \\
\text { c. } 21-23\end{array}$ & $\begin{array}{l}\mathrm{RO} / \mathrm{AS} \\
\mathrm{c} .24-27\end{array}$ & $\begin{array}{l}\text { R\&D } \\
\text { c. } 28-34\end{array}$ & $\begin{array}{l}\text { Con } \\
\text { c. } 67-69\end{array}$ & $\begin{array}{l}\text { Sug } \\
\text { c. } 70-74\end{array}$ & & \\
\hline
\end{tabular}

Main Parts:

\begin{tabular}{|l|}
\hline GS \\
\hline$(\& P r)$ \\
\hline SI \\
\hline TI \\
\hline B \\
\hline S \\
\hline C \\
\hline
\end{tabular}

Greeting and Salutation and Prayer Self Introduction Topic Introduction The Body The Summary The Conclusion
Part of the Body:

\begin{tabular}{|c|c|}
\hline $\mathrm{Bg}$ & Background of the Final Project \\
\hline OS & Object of Study \\
\hline $\mathrm{PI} / \mathrm{PS}$ & Problem Identification or Problem Statement \\
\hline $\mathrm{RO} / \mathrm{AS}$ & Research Objective(s) or Aims of the Study \\
\hline $\mathrm{MI} / \mathrm{RM}$ & Method of Investigation or Research Method \\
\hline LR/TF & Literature Review or Theoretical Framework \\
\hline $\mathrm{R} \& \mathrm{D}$ & Results and Discussion \\
\hline
\end{tabular}

Part of S (Summary):

\begin{tabular}{ll}
\hline Con & Conclusion \\
\cline { 1 - 1 } Sug & Sugestion
\end{tabular}

Note: $\mathrm{c} .1=$ clause no. $1, \mathrm{c} .2=$ clause no. 2 , etc . 
Table 7. Grammatical cohesive devices: Conjunction

\begin{tabular}{llll}
\hline & Textual & Hypotactic & Paratactic \\
\hline Data 1 & 16 & 14 & 15 \\
Data 2 & 40 & 8 & 4 \\
Data 3 & 30 & 0 & 3 \\
Data 4 & 14 & 30 & 11 \\
Data 5 & 7 & 6 & 0 \\
Data 6 & 4 & 4 & 4 \\
Data 7 & 10 & 5 & 0 \\
Data 8 & 0 & 2 & 2 \\
Data 9 & 6 & 2 & 3 \\
Data 10 & 7 & 5 & 1 \\
Data 11 & 7 & 6 & 14 \\
Data 12 & 3 & 10 & 17 \\
Data 13 & 10 & 1 & 0 \\
Data 14 & 5 & 1 & 5 \\
\hline Total & $\mathbf{1 5 9}$ & $\mathbf{9 4}$ & $\mathbf{7 9}$ \\
\hline \% & $\mathbf{4 8 \%}$ & $\mathbf{2 8 \%}$ & $\mathbf{2 4 \%}$ \\
\hline
\end{tabular}

Table 8. Grammatical cohesive devices: Conjunction

\begin{tabular}{lllll}
\hline & Pronominals & Demonstratives & Definite Articles & Comparatives \\
\hline Data 1 & 23 & 4 & 24 & 2 \\
Data 2 & 4 & 3 & 24 & 2 \\
Data 3 & 22 & 4 & 31 & 2 \\
Data 4 & 18 & 20 & 78 & 2 \\
Data 5 & 5 & 2 & 31 & 0 \\
Data 6 & 10 & 1 & 29 & 2 \\
Data 7 & 14 & 1 & 16 & 2 \\
Data 8 & 8 & 1 & 15 & 0 \\
Data 9 & 23 & 4 & 29 & 1 \\
Data 10 & 7 & 7 & 51 & 3 \\
Data 11 & 17 & 6 & 39 & 0 \\
Data 12 & 18 & 15 & 48 & 6 \\
Data 13 & 5 & 3 & 33 & 0 \\
Data 14 & 9 & 8 & 32 & 2 \\
\hline TOTAL & $\mathbf{1 8 3}$ & $\mathbf{7 9}$ & $\mathbf{4 8 0}$ & $\mathbf{2 4}$ \\
\hline \% & $24 \%$ & $10 \%$ & $63 \%$ & $3 \%$ \\
\hline
\end{tabular}

Table 9. Lexical Cohesive Devices: General Type

\begin{tabular}{|c|c|c|c|c|c|c|c|c|c|c|}
\hline & \multicolumn{2}{|c|}{ REPETITION } & \multicolumn{2}{|c|}{ SYNONYMY } & \multicolumn{2}{|c|}{ ANTONYMY } & \multicolumn{2}{|c|}{ HYPONYMY } & \multicolumn{2}{|c|}{ MERONYMY } \\
\hline & Chains & Tokens & Chains & Tokens & Chains & Tokens & Chains & Tokens & Chains & Tokens \\
\hline Data 1 & 8 & 50 & 0 & 0 & 3 & 6 & 0 & 0 & 0 & 0 \\
\hline Data 2 & 7 & 43 & 0 & 0 & 1 & 2 & 0 & 0 & 0 & 0 \\
\hline Data 3 & 7 & 43 & 0 & 0 & 0 & 0 & 0 & 0 & 0 & 0 \\
\hline Data 4 & 6 & 54 & & & 2 & 4 & & & & \\
\hline Data 5 & 4 & 32 & & & & & & & & \\
\hline Data 6 & 3 & 25 & & & & & 4 & 12 & 1 & 2 \\
\hline Data 7 & 3 & 15 & & & & & 1 & 3 & & \\
\hline Data 8 & 3 & 19 & & & & & & & & \\
\hline Data 9 & 4 & 25 & & & 1 & 2 & & & 3 & 9 \\
\hline Data 10 & 4 & 31 & 1 & 2 & 2 & 4 & & & 1 & 4 \\
\hline Data 11 & 5 & 19 & & & 1 & 2 & & & & \\
\hline Data 12 & 3 & 6 & 0 & 0 & 1 & 2 & 0 & 0 & 0 & 0 \\
\hline Data 13 & 3 & 14 & & & 1 & 2 & & & & \\
\hline Data 14 & 2 & 16 & 1 & 2 & 1 & 2 & & & & \\
\hline Total & 62 & 392 & 2 & 4 & 13 & 26 & 5 & 15 & 5 & 15 \\
\hline$\%$ & $71 \%$ & $87 \%$ & $2 \%$ & $1 \%$ & $15 \%$ & $6 \%$ & $6 \%$ & $3 \%$ & $6 \%$ & $3 \%$ \\
\hline
\end{tabular}


Table 10. Elements Used as the Stage Markers in the Presentations

\begin{tabular}{|c|c|c|c|c|c|c|c|c|c|c|c|c|}
\hline No. & Stage1 & Stage 1>2 & Stage $2>3$ & $\begin{array}{l}\text { Stage 3>4 } \\
\text { (Sub Stage } \\
\text { 1) }\end{array}$ & $\begin{array}{l}\text { Sub-Stage } \\
1>2\end{array}$ & $\begin{array}{l}\text { Sub-Stage } \\
2>3\end{array}$ & $\begin{array}{l}\text { Sub-Stage } \\
3>4\end{array}$ & $\begin{array}{l}\text { Sub- } \\
\text { Stage } \\
4>5\end{array}$ & $\begin{array}{l}\text { Sub- } \\
\text { Stage } \\
5>6\end{array}$ & Stage $4>5$ & Con $>$ Sug & Stage $5>6$ \\
\hline Prsntn 1 & Salam & $\begin{array}{l}\text { (Marked } \\
\text { Theme) }\end{array}$ & $\begin{array}{l}\text { Ellipsis } \\
\text { (S) }\end{array}$ & $\begin{array}{l}\text { Repetition } \\
\text { (PKKDS) }\end{array}$ & $\begin{array}{l}\text { Marked } \\
\text { Theme }\end{array}$ & $\begin{array}{l}\text { Marked } \\
\text { Theme }\end{array}$ & $\begin{array}{l}\text { Marked } \\
\text { Theme }\end{array}$ & & & $\begin{array}{l}\text { Marked } \\
\text { theme }\end{array}$ & $\begin{array}{l}\text { Marked } \\
\text { theme }\end{array}$ & $\begin{array}{l}\text { Tex.Conj. } \\
\text { (Okay) }\end{array}$ \\
\hline Prsntn 2 & Greeting & $\begin{array}{l}\text { (Marked } \\
\text { Theme) }\end{array}$ & $\begin{array}{l}\text { Text.Conj. } \\
\text { (The first) }\end{array}$ & $\begin{array}{l}\text { Lex.Item: } \\
\text { Background }\end{array}$ & $\begin{array}{l}\text { Lex.Item: } \\
\text { Problem }\end{array}$ & $\begin{array}{l}\text { Lex.Item: } \\
\text { Research }\end{array}$ & $\begin{array}{l}\text { Lex.Item: } \\
\text { Results }\end{array}$ & & & $\begin{array}{l}\text { Lex.Item: } \\
\text { Conclusion }\end{array}$ & $\begin{array}{l}\text { Lex.Item: } \\
\text { Suggestion }\end{array}$ & $\mathrm{X}$ \\
\hline Prsntn 3 & Salam & $\begin{array}{l}\text { Text.Conj. } \\
\text { (Okay) }\end{array}$ & $\begin{array}{l}\text { Text.Conj. } \\
\text { (So) }\end{array}$ & Ellipsis (S) & $\begin{array}{l}\text { Lex.Item: } \\
\text { Problem }\end{array}$ & $\begin{array}{l}\text { Lex.Item: } \\
\text { Aims }\end{array}$ & $\begin{array}{l}\text { Lex.Item: } \\
\text { Accounting }\end{array}$ & & & $\begin{array}{l}\text { Tex.Conj. } \\
\text { (Yes, and) }\end{array}$ & $\mathrm{X}$ & $\begin{array}{l}\text { Tex.Conj. } \\
\text { (Well) }\end{array}$ \\
\hline Prsntn 4 & Salam & Ref. I & $\begin{array}{l}\text { (Marked } \\
\text { Theme) }\end{array}$ & $\begin{array}{l}\text { Ref. This } \\
\text { (project) }\end{array}$ & Ref. This & $\begin{array}{l}\text { Voc.Theme: } \\
\text { Ladies }\end{array}$ & & & & $\begin{array}{l}\text { Marked } \\
\text { theme }\end{array}$ & $\begin{array}{l}\text { Marked } \\
\text { theme }\end{array}$ & $\begin{array}{l}\text { Ref.Theme } \\
\text { (That) }\end{array}$ \\
\hline Prsntn 5 & Greeting & Ref. My & $\begin{array}{l}\text { (Marked } \\
\text { Theme) }\end{array}$ & $\begin{array}{l}\text { Lex.Item: } \\
\text { Background }\end{array}$ & Ref. The & $\begin{array}{l}\text { Lex.Item: } \\
\text { Purpose }\end{array}$ & $\begin{array}{l}\text { Lex.Item: } \\
\text { Method }\end{array}$ & $\begin{array}{l}\text { Lex.Item: } \\
\text { Result }\end{array}$ & & $\begin{array}{l}\text { Lex.Item: } \\
\text { Conclusion }\end{array}$ & $\begin{array}{l}\text { Lex.Item: } \\
\text { Suggestion }\end{array}$ & $\begin{array}{l}\text { Theme } \\
\text { (Thank you) }\end{array}$ \\
\hline Prsntn 6 & Greeting & $\begin{array}{l}\text { (Marked } \\
\text { Theme) }\end{array}$ & Ref. I & $\begin{array}{l}\text { Lex.Item: } \\
\text { Background }\end{array}$ & $\begin{array}{l}\text { Lex.Item: } \\
\text { Problem }\end{array}$ & $\begin{array}{l}\text { Tex.Conj. } \\
\text { (And) }\end{array}$ & $\begin{array}{l}\text { Lex.Item: } \\
\text { Accounting }\end{array}$ & & & $\begin{array}{l}\text { Tex.Conj. } \\
\text { (And) }\end{array}$ & $X$ & $\begin{array}{l}\text { Tex.Conj. } \\
\text { (OK) }\end{array}$ \\
\hline Prsntn 7 & Salam & Ref. My & $\begin{array}{l}\text { (Marked } \\
\text { Theme) }\end{array}$ & $\begin{array}{l}\text { Lex.Item: } \\
\text { Background }\end{array}$ & $\begin{array}{l}\text { Tex.Conj. } \\
\text { (And next) }\end{array}$ & $\begin{array}{l}\text { Ref. The } \\
\text { (next) }\end{array}$ & $\begin{array}{l}\text { Tex.Conj. } \\
\text { (And) }\end{array}$ & & & $\begin{array}{l}\text { Marked } \\
\text { theme }\end{array}$ & $\begin{array}{l}\text { Tex.Conj. } \\
\text { (Next) }\end{array}$ & Ref. I \\
\hline Prsntn 8 & Greeting & Ref. My & Ref. I & $\begin{array}{l}\text { Ref. The } \\
\text { (Background) }\end{array}$ & $\begin{array}{l}\text { Lex.Item: } \\
\text { Formulation }\end{array}$ & $\begin{array}{l}\text { Lex.Item: } \\
\text { Research }\end{array}$ & $\begin{array}{l}\text { Lex.Item: } \\
\text { Recap. }\end{array}$ & & & $\begin{array}{l}\text { Ref. The } \\
\text { (conclusion) }\end{array}$ & $\begin{array}{l}\text { Tex.Conj. } \\
\text { (OK) }\end{array}$ & $\begin{array}{l}\text { Theme } \\
\text { (Thank you) }\end{array}$ \\
\hline Prsntn 9 & Salam & $\begin{array}{l}\text { Text.Conj. } \\
\text { (Firstly) }\end{array}$ & Ref. I & $\begin{array}{l}\text { Inter.Theme } \\
\text { (Why did) }\end{array}$ & $\begin{array}{l}\text { Lex.Item: } \\
\text { Problem }\end{array}$ & $\begin{array}{l}\text { Lex.Item: } \\
\text { Aims }\end{array}$ & $\begin{array}{l}\text { Lex.Item: } \\
\text { Theoretical }\end{array}$ & Ref. This & & $\mathrm{X}$ & $\begin{array}{l}\text { Tex.Conj. } \\
\text { (And) }\end{array}$ & $\begin{array}{l}\text { Tex.Conj. } \\
\text { (And) }\end{array}$ \\
\hline Prsntn 10 & Salam & Ref. My & Ref. I & $\begin{array}{l}\text { Lex.Item: } \\
\text { Background }\end{array}$ & $\begin{array}{l}\text { Lex.Item: } \\
\text { Problem }\end{array}$ & $\begin{array}{l}\text { Lex.Item: } \\
\text { Aims }\end{array}$ & $\begin{array}{l}\text { Lex.Item: } \\
\text { Theoretical }\end{array}$ & $\begin{array}{l}\text { Lex.Item: } \\
\text { Method }\end{array}$ & $\begin{array}{l}\text { Lex.Item: } \\
\text { Result }\end{array}$ & $\begin{array}{l}\text { Lex.Item: } \\
\text { Conclusion }\end{array}$ & $\begin{array}{l}\text { Lex.Item: } \\
\text { PT NMS }\end{array}$ & Ref. I \\
\hline Prsntn 11 & Salutation & Ref. My & $\begin{array}{l}\text { (Marked } \\
\text { Theme) }\end{array}$ & $\begin{array}{l}\text { Tex.Conj. } \\
\text { (Now) }\end{array}$ & $\begin{array}{l}\text { Tex.Conj. } \\
\text { (And then) }\end{array}$ & $\begin{array}{l}\text { Tex.Conj. } \\
\text { (And then) }\end{array}$ & $\begin{array}{l}\text { Tex.Conj. } \\
\text { (And then) }\end{array}$ & & & $X$ & & Ref. That \\
\hline Prsntn 12 & Salam & Ref. My & Ref. I & $\begin{array}{l}\text { (Marked } \\
\text { Theme) }\end{array}$ & $\begin{array}{l}\text { Tex.Conj. } \\
\text { (And then) }\end{array}$ & $\begin{array}{l}\text { Tex.Conj. } \\
\text { (And then) }\end{array}$ & $\begin{array}{l}\text { Tex.Conj. } \\
(\mathrm{OK})\end{array}$ & & & $\begin{array}{l}\text { Tex.Conj. } \\
\text { (OK) }\end{array}$ & $\begin{array}{l}\text { Tex.Conj. } \\
\text { (And then) }\end{array}$ & $\begin{array}{l}\text { Tex.Conj. } \\
\text { (OK) }\end{array}$ \\
\hline Prsntn 13 & Salam & Ref. I & $\begin{array}{l}\text { Para.Conj. } \\
\text { and }\end{array}$ & $\begin{array}{l}\text { Ref. The } \\
\text { (Object) }\end{array}$ & Ref. The & $\begin{array}{l}\text { Ref. The } \\
\text { (Research) }\end{array}$ & Ref. This & & & $\mathrm{X}$ & & Ref. This \\
\hline Prsntn 14 & Salam & $\begin{array}{l}\text { (Marked } \\
\text { Theme) }\end{array}$ & Ref. My & $\begin{array}{l}\text { Ref. The } \\
\text { (first) }\end{array}$ & $\begin{array}{l}\text { Tex.Conj. } \\
\text { (And) }\end{array}$ & $\begin{array}{l}\text { Tex.Conj. } \\
\text { (And then) }\end{array}$ & Ref. This & & & $\begin{array}{l}\text { Tex.Conj. } \\
\text { (And then) }\end{array}$ & $\begin{array}{l}\text { Tex.Conj. } \\
\text { (And then) }\end{array}$ & $\begin{array}{l}\text { Theme } \\
\text { (Thank you) }\end{array}$ \\
\hline
\end{tabular}

\begin{tabular}{c}
\hline GS \\
\hline SI \\
\hline TI \\
\hline
\end{tabular}

Greeting and Salutation

Self Introduction

Topic Introduction

The Body

The Summary

The Conclusion 